\title{
Proapoptotic and Anticancer Potentials of Thymus capitatus Essential Oil on Colon Cancer Stem Cells
}

\author{
Dudu Özkum Yavuz' ${ }^{\mathrm{D}}$, Eda Becer ${ }^{2,3}$ (D) Remziye Kendirci ${ }^{4}$ (D) Feyzan Özdal Kurt ${ }^{5}$ (D), \\ H. Seda Vatansever ${ }^{3,4}$ (D) \\ 'Department of Pharmaceutical Botany, Near East University, Faculty of Pharmacy, Nicosia, Cyprus \\ ${ }^{2}$ Department of Biochemistry, Near East University, Faculty of Pharmacy, Nicosia, Cyprus \\ ${ }^{3}$ Near East University, DESAM Institute, Nicosia, Cyprus \\ ${ }^{4}$ Department of Histology and Embryology, Manisa Celal Bayar University, Faculty of Medicine, Manisa, Turkey \\ ${ }^{5}$ Department of Biology, Manisa Celal Bayar University, Faculty of Sciences and Letter, Manisa, Turkey
}

ORCID iDs of the authors: D.Ö.Y. 0000-000I-8743-8862; E.B. 0000-0002-2378-I28X; R.K. 0000-0002-6839-8823; F.Ö.K. 0000-000I-60703742; H.S.V. 0000-0002-7415-9618.

Cite this article as: Yavuz DÖ, Becer E, Kendirci R, Kurt FÖ, Vatansever HS. Proapoptotic and Anticancer Potentials of Thymus Capitatus Essential Oil On Colon Cancer Stem Cells. Cyprus J Med Sci. 2021; 6(4): 319-324.

\section{BACKGROUND/AIMS}

The aim of this study was to investigate the proapoptotic activity of Thymus capitatus essential oil in either colon cancer stem (CDI33+ Colo-320) or nonstem (CDI33- Colo-320) cells.

\section{MATERIAL and METHODS}

T. capitatus essential oil was obtained by water distillation and analyzed by GC-MS. Cancer stem cells (CDI33+ Colo-320) were obtained from the Colo-320 cells by the MiniMACS system. Proapoptotic activity of T. capitatus essential oil was investigated by immunocytochemistry using antibodies directed against caspase-3 and terminal deoxynucleotidyl transferase dUTP nick end labeling (TUNEL) assay.

\section{RESULTS}

Caspase-3 immunoreactivity was significantly increased in $0.5 \%$ dilution T. capitatus essential oil-treated Colo- 320 cells for 48 hours. Moreover, the number of TUNEL positive cells was significantly higher in Colo-320 cells when compared with CDI33+ and CDI33- Colo320 cells.

\section{CONCLUSION}

We conclude that T. capitatus essential oil increases caspase-3 molecules, which play a crucial role in apoptosis. Interestingly, T. capitatus essential oil is found to be more effective in Colo-320 cells than CDI33+ Colo-320 and CDI33- Colo-320 cells in terms of apoptosis.

Keywords: Thymus capitatus, essential oil, apoptosis, colon cancer

\section{INTRODUCTION}

Colorectal cancer is the fourth leading cause of cancer-associated mortality and composed of heterogeneous cell populations. Metastasis and disease relapse are the critical challenges in the management of colorectal cancer. The cancer stem cells are a group of tumor cells with self-renewal characteristics and multidirectional differentiation potential. Also, they are closely related to tumor metastasis, recurrence after primary treatment, and drug resistance in colorectal cancer.' Colorectal cancer stem cells have surface markers that are used for identification such as CDI33. CDI33, a transmembrane glycoprotein, containing colorectal cancer cells (CDI33+) is resistant to radio- and chemotherapy and associated with tumor size. ${ }^{2}$

Apoptosis is a cell suicide pathway for normal cell turnover, managing stress and maintaining tissue homeostasis. The intrinsic (mitochondrial) and extrinsic (death receptor) pathways are important apoptotic pathways. Caspase-3 cleavage is stimulated by both apoptotic pathways. The caspase-3 activation results in inducing DNA fragmentation, cytoskeletal and nuclear proteins degradation, formation of apoptotic bodies, and finally, uptake by phagocytic cells. 
Apoptosis is a safeguard mechanism against tumorigenesis. ${ }^{3}$ However, cancer cells become resistant to apoptosis as a result of epigenetic variations and mutations in genes that control mitosis such as adenomatous polyposis coli (APC6) and P53 in colorectal cancer.' In particular, deregulations of apoptotic pathways are shown in colorectal cancer stem cells that are resistant to cancer therapies. In recent years, several researchers have focused on drug discovery and combination therapy that are specific for genetic mutations and selective induction of apoptosis in colorectal cancer. The crucial roles of several plant products such as oils, gums, alkaloids, flavonoids, biomolecules in inhibiting cancer cell activating proteins, enzymes, and signaling pathways with their less toxic effect in adjuvant cancer therapy have been shown in extensive research. ${ }^{4}$ For example, essential oil from Libyan Thymus capitatus indicated cytotoxicity activities against human cell lines such as MRC-5, HCT $\| 6$, and HT-29. ${ }^{5}$

T. capitatus is a species of the genus of Lamiaceae, which contains over 300 species of hardy perennial herbaceous plants. It is a native species in the Mediterranean region. ${ }^{6}$ Also, T. capitatus is economically the most important genera employed by the cosmetic and fragrance industries. In traditional medicine, thyme tea is consumed against gastro-intestinal disorders, and its essential oil is also used for expelling intestinal parasites. ${ }^{7}$ Previous studies have shown that $T$. capitatus essential oil has antiseptic, antioxidant, and also antimicrobial properties. ${ }^{5,8-I I}$ T. capitatus has a potential thymol (62.3\%) source, thymol chemotype according to the previous results. ${ }^{12}$ T. capitatus essential oil has a variety of different biological activities. In particular, the anticancer effects of thymol are known, while the antioxidant, anti-inflammatory/immunomodulatory, and antigenotoxicity properties have also been shown. ${ }^{13}$

There are only a few studies associated with the cytotoxic activities of $T$. capitatus essential oil., 514 To the best of our knowledge, no work has been carried out on the effects of $T$. capitatus essential oil on colon cancer with in vitro and in vivo studies. The specific effects of $T$. capitatus essential oil with respect to proapoptotic signaling pathway molecules in both colon carcinoma cells and colon cancer stem cells remain undefined. The aims of this study were: (i) to compare the effects of different dilutions of $T$. capitatus essential oil with respect to their proapoptotic activities in Colo-320, CDI33+, and CDI33-Colo-320 cells and (ii) to determine the proapop-

\section{Main Points}

- In this study, our results showed that Thymus capitatus essential oil from Northern Cyprus stimulated apoptosis in primary human colon adenocarcinoma cell line (Colo320).

- It was found that CDI33+ Colo-320 cells (cancer stem cells) may be have resistance to Thymus capitatus essential oil. However, apoptosis was stimulated in Colo-320 cells which include both CDI33+ Colo-320 and CDI33Colo-320 cells.

- Interestingly, apoptosis was stimulated in \%0.5 dilution Thymus capitatus essential oil treated Colo-320 cells. \%l and $\% 2$ dilutions of essential oil were not showed effective proapoptotic properties.

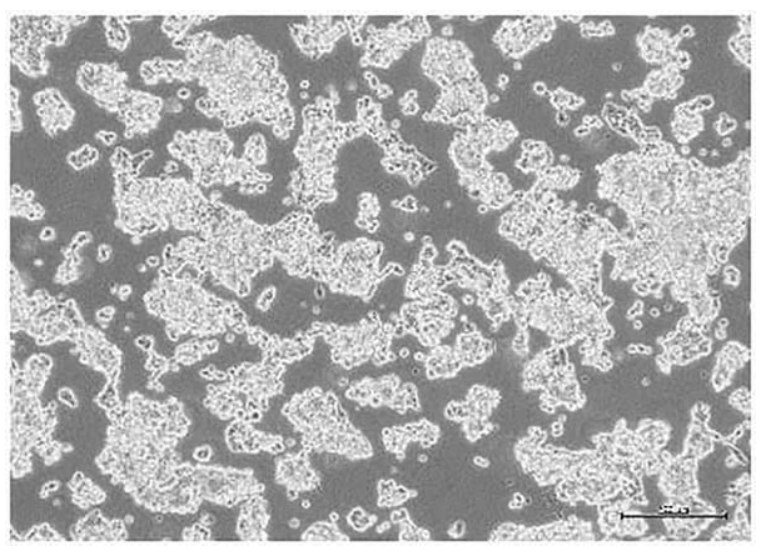

Figure I. Colo-320 cells imaged under the inverted microscope. Scale bar $=200 \mu \mathrm{m}$.

totic effects of $T$. capitatus essential oil via caspase-3 expression in Colo-320, CDI33+, and CDI33- Colo-320 cells.

\section{MATERIAL and METHODS}

The plant materials, isolation of the essential oil, and GC/MS analysis in this study are in parallel with those used in previous studies. $^{12}$

\section{Cell Line and Cell Culture}

In this study, primary human colon adenocarcinoma cell line (Colo-320 (ATCC: CCL220)) was used, and cells were maintained in RPMI 1640 containing 10\% fetal bovine serum (Capricorn Scientific, FBS-HI-IIB), I\% L-glutamine (Capricorn Scientific, GLN-B), and $1 \%$ penicillin-streptomycin (Capricorn Scientific, PS-B) (Figure I). Cells were cultured in a humidified atmosphere at $37^{\circ} \mathrm{C}$ and $5 \% \mathrm{CO}_{2}$ culture condition. Cells subcultured when they reached $70-80 \%$ confluency.

\section{Isolation of CDI33+ Cells with Immunomagnetic System}

Primary human colon adenocarcinoma (Colo-320) CDI33+ cancer stem cells were separated from Colo-320 cells using a MiniMACS system (Miltenyi Biotec, Germany). Buffer (Miltenyi Biotec, Germany, 130-100-857) was used for the preparation of Colo-320 cells $\left(2 \times 10^{8}\right.$ cells $\left./ \mathrm{mL}\right)$ suspension. Then, FcR blocking reagent (Miltenyi Biotec, Germany, 130-100-857) was added. Cells were incubated in stirring on ice for $30 \mathrm{~min}$ after antibody-labeled CDI33 microbeads (Miltenyi Biotec, Germany, 130-100-857) adding. Cells washed with buffer and centrifuged for $10 \mathrm{~min}$. Resuspension of cells was performed using buffer after the removal of supernatant. Magnetic field was used for magnetic separation. Column was washed using buffer, and then the CDI33 cells were collected in a tube. The column was took out from the magnetic field and washed with buffer to collect the CDI33+ Colo-320 cells in another tube. The cells were centrifuged for 10 minutes, and then the buffer was removed. CDI33+ and CDI33- Colo-320 cells were transferred into a flask and cultured separately.

\section{Cultivation of Cells with $T$. capitatus Essential Oil}

According to their types, cells were disunited into three groups. Colo-320, CDI33+ Colo-320, and CDI33- Colo-320 cells were our study groups. Also, three cell groups were divided into three subgroups and incubated for 48 hours. These were $0.5 \%$ 

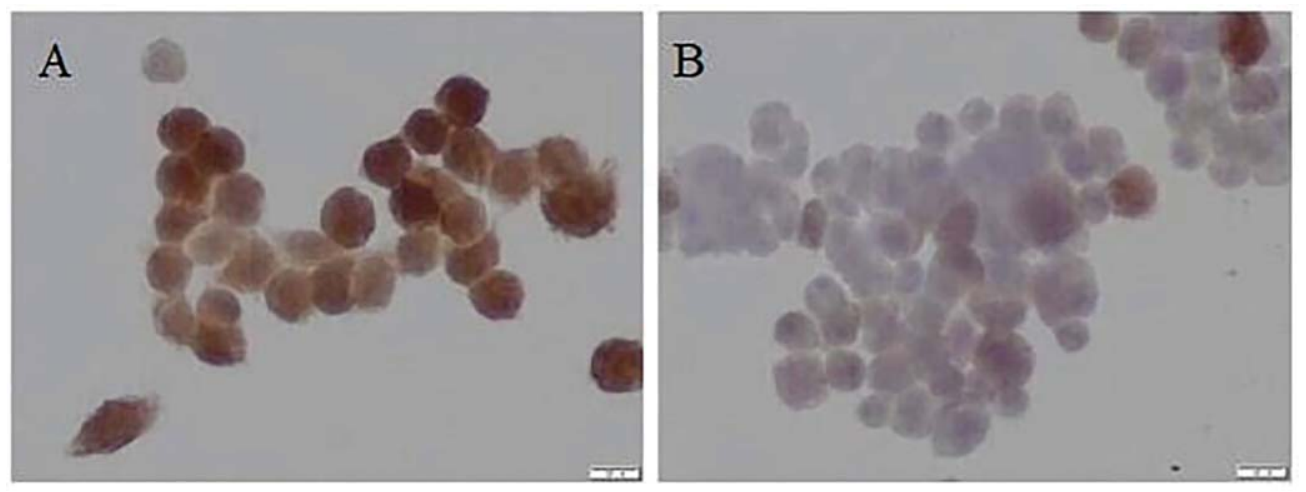

Figure 2. Colo-320 CDI33+ cells (A), and CDI33- cells (B) achieved from Colo-320 cell line by MiniMACS. Scale bars = $10 \mu \mathrm{m}$.

of $T$. capitatus essential oil treated cell group, $1 \%$ T. capitatus essential oil treated cell group, and $2 \%$ T. capitatus essential oil cell group.

\section{Immunocytochemistry}

To evaluate cell responses to $T$. capitatus essential oil, caspase-3 (sc-7272, Santa Cruz Biotechnology, Inc., USA) distribution on the Colo-320, CDI33+ and CDI33-Colo-320 cells was analyzed using previously described indirect immunoperoxidase staining protocol. ${ }^{15}$

H-SCORE was used for graded semi-quantitatively graded of caspase-3 staining. In H-SCORE $=\Sigma_{л}(\mathrm{i}+\mathrm{l})$ formula, $\mathrm{i}$ is the intensity of dyeing with a value of $\mathrm{l}, 2$, or 3 (mild, moderate, or strong, respectively). $\pi$ is the percentage of cells stained (between 0 and $100 \%$ ) with each intensity.

\section{TUNEL Assay}

To detect the apoptotic DNA fragmentation, the TUNEL (terminal deoxynucleotidyl transferase dUTP nick end labeling) assay was used. TUNEL assay was performed as described previously. ${ }^{15}$

\section{Statistical Analysis}

The data were expressed as mean \pm standard deviation (SD). The GraphPad Prism 7 software was used for analysis, and group differences were analyzed using the Kruskal-Wallis test. The differences in the mean values of continuous variables in the three genotype subgroups were confirmed by a post hoc Dunn test. A $P<.05$ was regarded as statistically significant.

\section{RESULTS}

\section{The Immunohistochemical Stain Analysis of CDI33+ Colo-320 and CDI33- Colo-320 Cells}

The CDI33+ cells (cancer stem cells) were achieved from the Colo-320 cells using the MiniMACS system. Immunocytochemical characterization of CDI33+, cancer stem cells, was performed using CDI33 antibody cell labeling. After immunostaining, the CDI33+ cells percentage was 88.8 (Figure 2A), and the CDI33+ cells intensity was higher than the CDI33- cells (Figure 2).

\section{Immunohistochemical Evaluation}

Strong caspase-3 immunostaining was detected in 0.5\% T. capitatus essential oil-treated Colo-320 cells (Figure 3A). Caspase-3
$\mathrm{H}$-SCORE was significantly higher in $0.5 \% \mathrm{~T}$. capitatus essential oiltreated Colo-320 cells than $2 \%$ T. capitatus essential oil-treated Colo-320 cells $(P=.0012$, Table I). According to the H-SCORE analysis, caspase-3 immunoreactivity was significantly higher in $0.5 \% T$. capitatus essential oil-treated Colo-320 cells (Figure 3A) than CDI33+ Colo-320 cells (Figure 3D) $(P=.017$, Table I).

Additionally, the immunoreactivity of caspase-3 was weak in $0.5 \%$ T. capitatus essential oil-treated CDI33- Colo-320 cells (Figure $3 \mathrm{G}$ ). The H-SCORE value of caspase- 3 was significantly lower in $0.5 \%$ T. capitatus essential oil-treated CDI33- Colo-320 cells in comparison to $0.5 \% \mathrm{~T}$. capitatus essential oil-treated Colo-320 cells $(P<.048$, Table I).

The immunostaining intensity of caspase- 3 was moderate in $0.5 \%, 1 \%$, and $2 \%$ dilution of $T$. capitatus essential oil-treated CDI33+ Colo-320 and CDI33- Colo-320 cells (Figure 3D-F and $3 \mathrm{G}-\mathrm{I}$ ). The immunoreactivity for caspase-3 was similar in all $T$. capitatus essential oil-treated CDI33+ Colo-320 and CDI33Colo-320 cells $(P<.05$, Table I).

\section{TUNEL Assay}

A TUNEL assay was used in Colo-320, CDI33+ Colo-320, and CDI33- Colo-320 cells. All cells were incubated with $0.5 \%$, $1 \%$, and $2 \%$ T. capitatus essential oil for 48 hours. In Colo-320 cells treated with $2 \%$ T. capitatus essential oil, the number of TUNEL positive cells was significantly lower than $0.5 \%$ T. capitatus essential oil-treated Colo-320 cells and I\% T. capitatus essential oil-treated Colo-320 cells, respectively $(P=.018$, Figure 4A and C, Table 2 and $P=.023$, Figure 4A and B, Table 2, respectively). Moreover, the number of TUNEL positive cells was highly significant in $0.5 \%$ T. capitatus essential oil-treated CDI33+ Colo320 cells when compared with $2 \%$ T. capitatus essential oiltreated CDI33+ Colo-320 cells $(P<.023$, Figure 4D and $F$, Table 2).

\section{DISCUSSION}

Globally, colorectal cancer is one of the common reasons of morbidity and mortality. Drug resistance, tumor metastasis, and recurrence after primary treatment are related to cancer stem cells in colorectal cancer. Radiotherapy and chemotherapy may relieve solid tumors, but they cannot kill cancer stem cells. In recent years, scientists have been focused on alternative therapies that target and effectively kill cancer stem cells. ${ }^{2}$ Among the alternative approaches, varied plant products such 


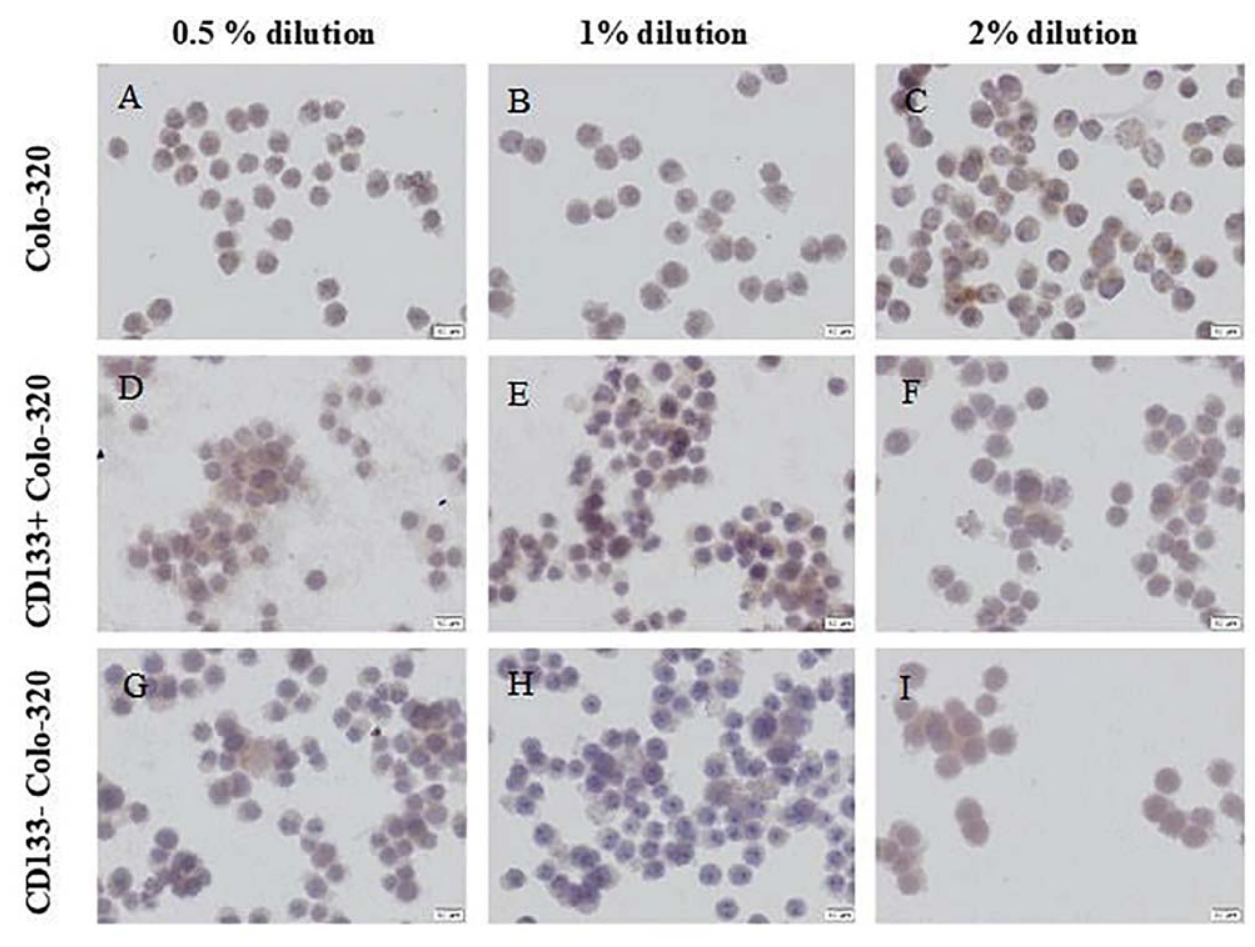

Figure 3. Immunoreactivity of caspase- 3 in $0.5 \%, 1 \%$ and $2 \%$ Thymus capitatus essential oil treated Colo-320 (A, B, C), CDI33+Colo320 (D, E, F) and CDI33-Colo-320 (G, H, I) cells for $48 \mathrm{~h}$. Scale bars $=10 \mu \mathrm{m}$

\begin{tabular}{|c|c|c|c|}
\hline & Colo-320 Cells & CDI33+ Colo-320 Cells & CDI33-Colo-320 Cells \\
\hline $1 \%$ dilution & $233.4 \pm 5.655$ & $124.6 \pm 5.678$ & $138.2 \pm 16.68$ \\
\hline $2 \%$ dilution & $161.8 \pm 34.45$ & $129.5 \pm 17.93$ & $149.2 \pm 21.17$ \\
\hline \multicolumn{4}{|c|}{$\begin{array}{l}{ }^{*} \text { The data were significant when compared with } 2 \% T \text {. capitatus essential oil-treated Colo- } 320 \text { cells }(P=.0012) \text {. } \\
{ }^{+} \text {The data were significant when compared with } 0.5 \% \text { T. capitatus essential oil-treated CDI33+Colo- } 320 \text { cells }(P=.017) \text {. } \\
\text { †The data were significant when compared with } 0.5 \% T \text {. capitatus essential oil-treated CDI33-Colo-320 cells }(P=.048) \text {. }\end{array}$} \\
\hline
\end{tabular}

as essential oils have demonstrated anticancer properties. Also, essential oils have been shown to improve the life quality of the cancer patients by lowering the side effects. ${ }^{16,17}$

Thymol is a natural monoterpene phenol derivative of cymene and a major component of the T. capitatus essential oil from Northern Cyprus. From the different experimental model study reports, thymol has been reported to exert anticancer activities through different mechanisms including inducing apoptosis, depolarizing mitochondrial membrane potential, and activating the proapoptotic caspase proteins. ${ }^{18-20}$ To date, only the cytotoxic and antimicrobial activities of the T. capitatus essential oil from Northern Cyprus have been reported, which is rich in thymol. ${ }^{20,21}$ No study has investigated the effects of $T$. capitatus essential oil from Northern Cyprus with respect to its proapoptotic effects in Colo-320, CDI33+ Colo-320, and CDI33- Colo320 cells. We showed that $0.5 \%$ of the T. capitatus essential oil is highly effective in activating the apoptosis in Colo-320 and CDI33+ Colo-320 cells.
Apoptotic signaling is important for maintaining balance between cell death and cell survival, and also the evasion of apoptosis is a prominent hallmark of cancer. Apoptosis is controlled by extrinsic and intrinsic mitochondrial pathways. Both pathways converge at caspase-3, an executioner caspase, which can elicit apoptosis, while caspase-3 is a crucial marker of apoptosis. Significant attention has been paid to developing varied experimental anticancer drugs that can target and modulate apoptotic pathways in recent years. ${ }^{3}$ Specifically, essential oils containing thymol have been reported to exert anticancer activities through different mechanisms such as inducing apoptosis and activating the proapoptotic proteins. Moreover, recent studies have reported that thymol stimulates apoptotic cell death via extrinsic and intrinsic mitochondrial pathways in different cancer cells. ${ }^{18-20,22}$ In our study, we showed that the immunoreactivity of caspase-3 was significantly higher in $0.5 \%$ diluted T. capitatus essential oil-treated Colo-320 cells than CDI33+ Colo-320 and CDI33- Colo-320 cells. In addition, the caspase- 3 immunoreactivity was higher in 


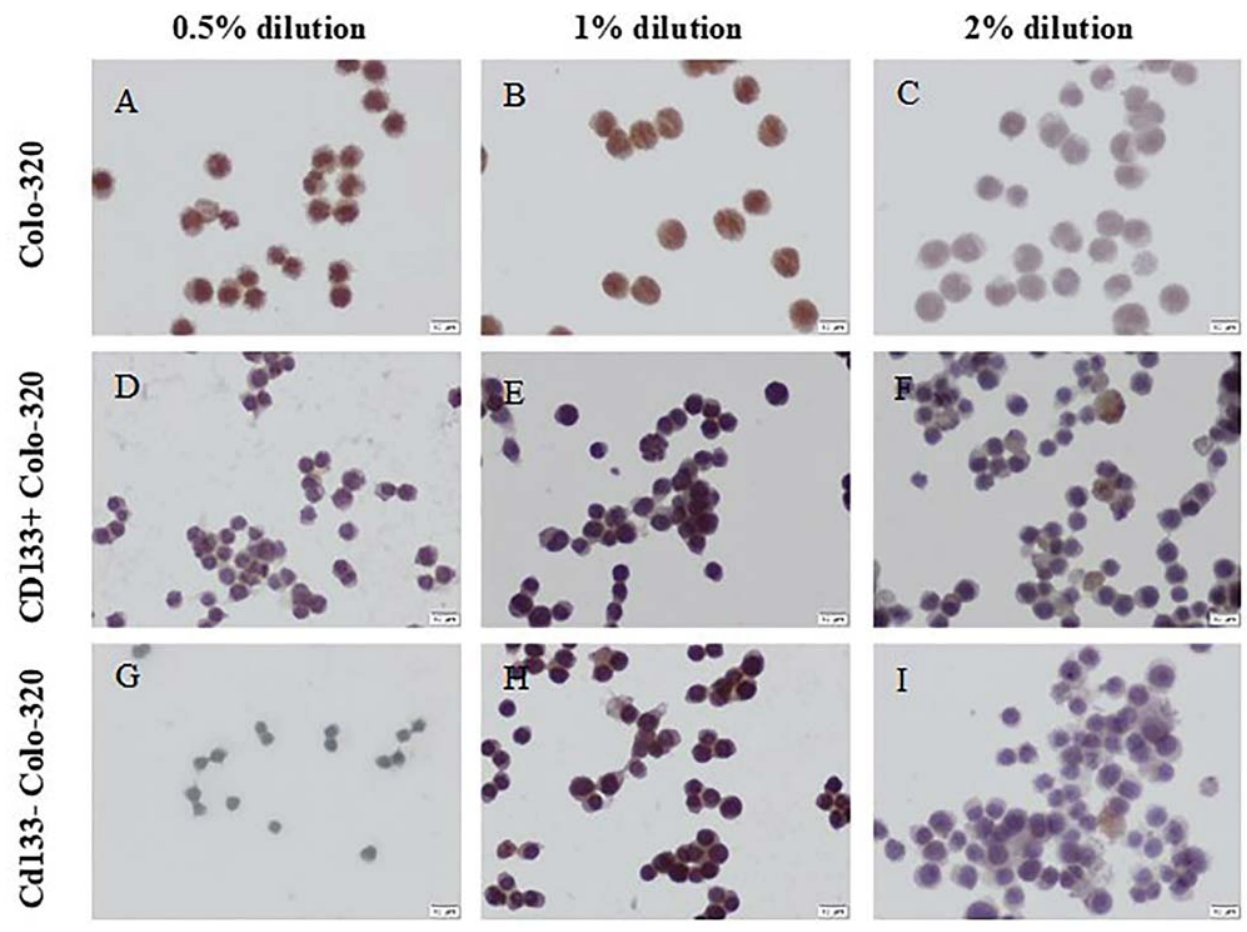

Figure 4. Evaluation of TUNEL staining in $0.5 \%, 1 \%$ and $2 \%$ Thymus capitatus essential oil treated Colo- 320 (A, B, C), CDI33+Colo320 (D, E, F) and CDI33-Colo-320 (G, H, I) cells for $48 \mathrm{~h}$ (Scale bars $=10 \mu \mathrm{m})$.

\begin{tabular}{|c|c|c|c|}
\hline & Colo-320 Cells & CDI33+ Colo-320 Cells & CDI33- Colo-320 Cells \\
\hline $1 \%$ dilution & $96.9 \pm 4.24$ & $10.98 \pm 4.27$ & $19 \pm 7.41$ \\
\hline $2 \%$ dilution & $48.97 \pm 12.39^{t . \neq}$ & $7.79 \pm 1.87$ & $12 \pm 2.73$ \\
\hline \multicolumn{4}{|c|}{ 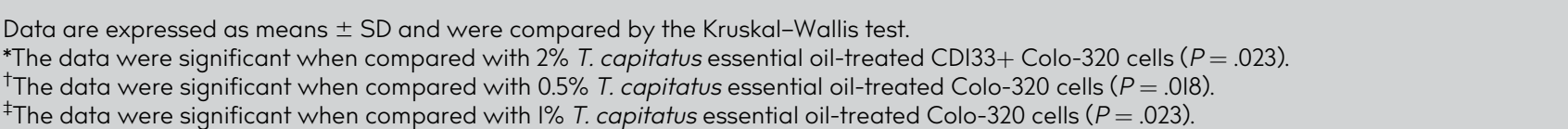 } \\
\hline
\end{tabular}

CDI33+ Colo-320 cells than CDI33-320 cells. Therefore, primary human colon adenocarcinoma cells treated with $0.5 \%$ diluted $T$. capitatus essential oil might be more effective on cancer stem cells. Additionally, the caspase-3 immunoreactivity was significantly higher in $0.5 \%$ diluted T. capitatus essential oil-treated Colo-320 cells than $2 \%$ diluted T. capitatus essential oil-treated Colo-320 cells. This result indicates that CDI33- Colo320 cells may have resistance to $T$. capitatus essential oil in the stimulation of apoptosis because of nonseparated Colo-320 cells. We speculate that the high amount of the thymol in $T$. capitatus essential oil may be the main reason for the caspase- 3 immunoreactivity upregulation in both Colo-320 cells that exerted anticancer properties. Moreover, we found that $0.5 \%$ diluted $T$. capitatus essential oil was more effective than other dilutions of essential oil in apoptosis stimulation in all cell types.

The TUNEL assay is used to detect apoptosis and imply a specificity for apoptosis. ${ }^{23}$ In line with the caspase-3 results, our TUNEL assay results showed that $T$. capitatus essential oil was more effective in Colo-320 cells than CDI33+ Colo-320 and
CDI33- Colo-320 cells. TUNEL positive cells were significantly higher in $2 \%$ and $1 \%$ diluted T. capitatus essential oil-treated Colo- 320 cells than $0.5 \%$ diluted $T$. capitatus essential oil-treated Colo-320 cells. Also, the TUNEL positive cell number was significantly higher in $0.5 \%$ diluted T. capitatus essential oil-treated CDI33+ Colo-320 cells compared to $2 \%$ diluted T. capitatus essential oil-treated CDI33+ Colo-320 cells. The meaning of the TUNEL positive cells is that they were triggered to cell death with different pathways, which were controlling either apoptosis or necrosis or necroptosis or other types of the cell death. However, the level of the caspase- 3 was indicated to apoptotic cells death. Therefore, our results indicated that $T$. capitatus essential oil is more effective in both Colo-320 cells and CDI33+ Colo-320 cells in terms of apoptotic DNA fragmentation.

In conclusion, we have demonstrated the proapoptotic and anticancer effects of $T$. capitatus essential oil in Colo-320, CDI33+ Colo-320, and CDI33- Colo-320 primary colon adenocarcinoma cell lines using various dilutions. Also, we compared the proapoptotic effects of three different dilutions of the $T$. 
capitatus essential oil in Colo-320, CDI33+ Colo-320, and CDI33- Colo-320 cells. Interestingly, $0.5 \%$ dilution of the T. capitatus essential oil elevated caspase-3 intensity and TUNEL positive cell number in Colo-320 cells. In order to verify the main proapoptotic and anticancer activities of $T$. capitatus essential oil on colon cancer cells, further assessment with different multiple signaling pathway molecules that include all possible apoptosis and cancer progression mechanisms is necessary.

Ethics Committee Approval: The study did not need Ethics Committee approval.

\section{Informed Consent: N/A.}

Peer-review: Externally peer-reviewed.

Author Contributions: Concept - D.Ö.Y., H.S.V.; Design - D.Ö.Y., H.S.V; Supervision - D.Ö.Y., H.S.V., F.Ö.K.; Resource - E.B., F.Ö.K., R.K., H.S.V., D.Ö.Y; Materials - F.Ö.K., R.K., H.S.V., D.Ö.Y; Data Collection and/or Processing - E.B., H.S.V., D.Ö.Y.; Analysis and/or Interpretation - E.B., F.Ö.K., R.K., H.S.V., D.Ö.Y; Literature Search - E.B., D.Ö.Y.; Writing - E.B., H.S.V., D.Ö.Y; Critical Reviews - E.B., F.Ö.K., R.K., H.S.V., D.Ö.Y.

Acknowledgments: The authors wish to thank Prof. Dr. Betül Demirci (Anadolu University, Faculty of Pharmacy, Pharmacognosy Department) for her valuable contribution to the isolation and analysis of the essential oil compositions and Yard. Doç. Dr. Azmi Hanoğlu (Near East University, Faculty of Pharmacy, Pharmacognosy Department) and Yard. Doç. Dr. Duygu Yiğit Hanoğlu (Near East University, Faculty of Pharmacy, Pharmaceutical Botany Department) for kindly providing the essential oil.

Conflict of Interest: The authors have no conflicts of interest to declare.

Financial Disclosure: The authors declared that this study has received no financial support.

\section{REFERENCES}

I. Dalerba P, Dylla SJ, Park IK, et al. Phenotypic characterization of human colorectal cancer stem cells. Proc Natl Acad Sci USA. 2007;104(24):I0I58-I0I63. [CrossRef]

2. Bu Y, Cao D. The origin of cancer stem cells. Front Biosci (Schol Ed). 2012;4:819-830. [CrossRef]

3. Cotter TG. Apoptosis and cancer: The genesis of a research field. Nat Rev Cancer. 2009;9(7):50I-507. [CrossRef]

4. Amin A, Gali-Muhtasib H, Ocker M, Schneider-Stock R. Overview of major classes of plant-derived anticancer drugs. Int J Biomed Sci. 2009;5(I):I-II.

5. Džamić AM, Nikolić BJ, Giweli AA, et al. Libyan Thymus capitatus essential oil: Antioxidant, antimicrobial, cytotoxic and colon pathogen adhesion-inhibition properties. J Appl Microbiol. 2015;1|9(2):389-399. [CrossRef]

6. Morales R. The genus Thymus L. in the Western Mediterranean region (Lamiaceae). Biocosme Mesogeen. 1989;6:205-211.

7. Figueiredo AC, Barroso JG, Pedro LG, Salgueiro L, Miguel MG, Faleiro ML. Portuguese Thymbra and thymus species volatiles: Chemical composition and biological activities. Curr Pharmaceut Des. 2008;14(29):3120-3|40. [CrossRef]
8. Cosentino $\mathrm{S}$, Tuberoso $\mathrm{Cl}$, Pisano B, et al. Palmas in-vitro antimicrobial activity and chemical composition of Sardinian thymus essential oils. Lett Appl Microbiol. 1999;29(2):130-135. [CrossRef]

9. Al-Mustafa AH, Al-Thunibat OY. Antioxidant activity of some Jordanian medicinal plants used traditionally for treatment of diabetes. Pakistan J Bio/ Sci. 2008;II(3):35I-358. [CrossRef]

10. Mkaddem MG, Romdhane $M$, Ibrahim $H$, et al. Essential oil of Thymus capitatus Hoff. et link. from Matmata, Tunisia: Gas chromatography-mass spectrometry analysis and antimicrobial and antioxidant activities. J Med Food. 20I0;13(6):1500-1504. [CrossRef]

II. Russo M, Suraci F, Postorino S, Serra D, Roccotelli A, Agosteo GE. Essential oil chemical composition and antifungal effects on Sclerotium cepivorum of Thymus capitatus wild populations from Calabria, Southern Italy. Braz J Pharmacog. 2013;23(2):239-248. [CrossRef]

12. Hanoglu A, Hanoglu DY, Demirci B, Özkum Yavuz D. Chemical composition of essential oil of the aerial parts of wild growing Thymus capitatus (L.) Hoffm. $\bar{\alpha}$ Link Species collected from three different locations in Northern Cyprus. J. Essent Oil Bear PI. 2017;20(2):54655I. [CrossRef]

13. Islam MT, Khalipha $A B$, Bagchi $R$, et al. Anticancer activity of thymol: A literature-based review and docking study with emphasis on its anticancer mechanisms. IUBMB Life. 2019;7|(I):9-19. [CrossRef]

14. Yavuz DÖ, Mavis M, Ateş $G$, et al. Identification of potential therapeutic role of thymus capitatus essential oil using cellular imaging. Procedia Comput Sci. 2017;120:961-966. [CrossRef]

15. Soykut G, Becer E, Calis I, Yucecan S, Vatansever S. Apoptotic effects of Corchorus olitorius L. leaf extracts in Colon adenocarcinoma cell lines. Prog Nutr. 2018;20:689-698.

16. Cragg GM, Newman DJ. Plants as a source of anti-cancer agents. J Ethnopharmacol. 2005;100(I-2):72-79. [CrossRef]

17. Bhalla Y, Gupta VK, Jaitak V. Anticancer activity of essential oils: A review. J Sci Food Agric. 2013;93(15):3643-3653. [CrossRef]

18. De La Chapa JJ, Singha PK, Lee DR, Gonzales CB. Thymol inhibits oral squamous cell carcinoma growth via mitochondriamediated apoptosis. J Oral Pathol Med. 2018;47(7):674-682. [CrossRef]

19. Deb DD, Parimala G, Devi SS, Chakraborty T. Effect of thymol on peripheral blood mononuclear cell PBMC and acute promyelotic cancer cell line HL-60. Chem Biol Interactions. 2011;193(I):97-I06. [CrossRef]

20. Llana-Ruiz-Cabello M, Gutiérrez-Praena D, Pichardo S, et al. Cytotoxicity and morphological effects induced by carvacrol and thymol on the human cell line caco-2. Food Chem Toxicol. 2014;64:28I-290. [CrossRef]

21. Guvenir M, Hanoglu D, Hanoglu A, et al. Antimicrobial activity of the essential oil of Thymus capitatus against Helicobacter Pylori. Acta Poloniae Pharmaceutica. 2020;77(I):155-160. [CrossRef]

22. Li Y, Wen JM, Du CJ, et al. Thymol inhibits bladder cancer cell proliferation via inducing cell cycle arrest and apoptosis. Biochem Biophys Res Commun. 2017;491(2):530-536. [CrossRef]

23. Loo DT. In situ detection of apoptosis by the TUNEL assay: An overview of techniques. In InDNA Damage Detection In Situ, Ex Vivo, and In Vivo. Totowa, NJ: Humana Press, 20ll: 3-I3. 